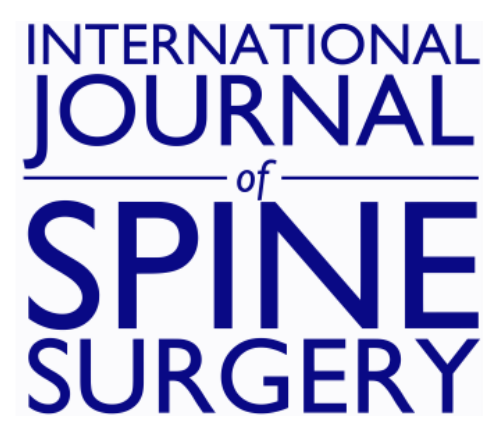

\title{
Correlation Between Modic Changes and Bacterial Infection: A Causative Study
}

\author{
SAURABH SINGH, G.I. SIDDHLINGESWARA, ALOK RAI, R. DINESH IYER, DIVYANSH \\ SHARMA and RISHABH SURANA
}

Int J Spine Surg 2020, 14 (5) 832-837

doi: https://doi.org/10.14444/7118

http://ijssurgery.com/content/14/5/832

This information is current as of April 25, 2023.

Email Alerts Receive free email-alerts when new articles cite this article. Sign up at:

http://ijssurgery.com/alerts

The International Journal of Spine Surgery

2397 Waterbury Circle, Suite 1,

Aurora, IL 60504, Phone: +1-630-375-1432 


\title{
Correlation Between Modic Changes and Bacterial Infection: A Causative Study
}

\author{
SAURABH SINGH, MS, MCH (ORTHO), G.I. SIDDHLINGESWARA, MS (ORTHO), ALOK RAI, MS \\ (ORTHO), R. DINESH IYER, MS (ORTHO), DIVYANSH SHARMA, MS (ORTHO), RISHABH SURANA, MS \\ (ORTHO) \\ Department of Orthopaedics, Institute of Medical Sciences, Banaras Hindu University, Varanasi, India
}

\begin{abstract}
Study Design: Prospective nonrandomized study.

Objective: Objective of the study was to ascertain etiological correlation between Modic changes (MC) and bacterial infection through 16s DNA sequencing in patients with chronic low backache.

Summary of Background Data: Modic changes are common on magnetic resonance imaging (MRI) of patients with low back pain and are strongly associated with low back pain. Various factors are associated with the etiology; of these, degeneration and mechanical factors are most common. Some studies have also found etiological relation between $\mathrm{MC}$ and infection.

Material and Method: The study involved 20 patients of either sex (age range, 20-65 years) who were investigated for blood count, erythrocyte sedimentation rate, and quantitative C-reactive protein. The intervertebral disc removed during discectomy from each patient was sent for polymerase chain reaction (PCR) study. We have targeted the conserved gene of the bacteria (ie, 16s ribosomal DNA) and used a universal eubacteria nested-amplification protocol that may detect picograms of bacterial DNA.

Result: Among the 20 cases of patients who had low back pain and MC in MRI, $13.5 \%$ showed raised leucocytosis, $28.6 \%$ showed raised erythrocyte sedimentation rate, $72.7 \%$ showed raised quantitative C-reactive protein, and $90 \%$ of the disc sample showed presence of bacteria in PCR study.
\end{abstract}

Conclusion: MC may have an infective etiology.

Level of Evidence: 4.

Other \& Special Categories

Keywords: Modic changes, PCR, MRI, low back pain, infection

\section{INTRODUCTION}

Modic changes (MC) are vertebral end plate and bone marrow signal changes seen on magnetic resonance imaging (MRI). de Roos et $\mathrm{al}^{1}$ first reported signal changes adjacent to the vertebral end plates visualized by MRI.

\section{Classification}

Radiologist Michael Modic and his colleagues ${ }^{2,3}$ described and classified MC. The MC are classified into 3 types: type 1 , type 2 , and type 3 . Modic changes type 1 (Figure 1) are seen as areas of high signal intensity on a T2 weighted image (T2WI) and as areas of low signal intensity on a $\mathrm{T} 1$ weighted image (T1WI). Modic changes type 2 (Figure 2) are seen as areas of high signal intensity on both T2WI and T1WI. Modic changes type 3 (Figure 3) are seen as areas of low signal intensity on both T2WI and T1WI. Modic changes type 1 contains vascular granulation tissue with inflammatory components, and MC type 2 contains fat replacement of hematopoietic tissue. Modic changes type 3 are rare and represent subchondral bony sclerosis. Miller ${ }^{4}$ classified MC in 4 grades. Grade 0 is normal, grade 1 is similar to MC type 1 , grade 2 is similar to MC type 2, and grade 3 is similar to MC type 3. Weishaupt et $\mathrm{al}^{5}$ also classified $\mathrm{MC}$ into 4 types on the basis of vertebral height involvement. MC type 1 can change over time to type 2 and vice versa. ${ }^{6}$

\section{Pathogenesis}

Multiple authors have found MC to be strongly associated with low back pain (LBP). Albert and Manniche ${ }^{7}$ found strong association between MC, mainly MC type 1, and nonspecific LBP. They 

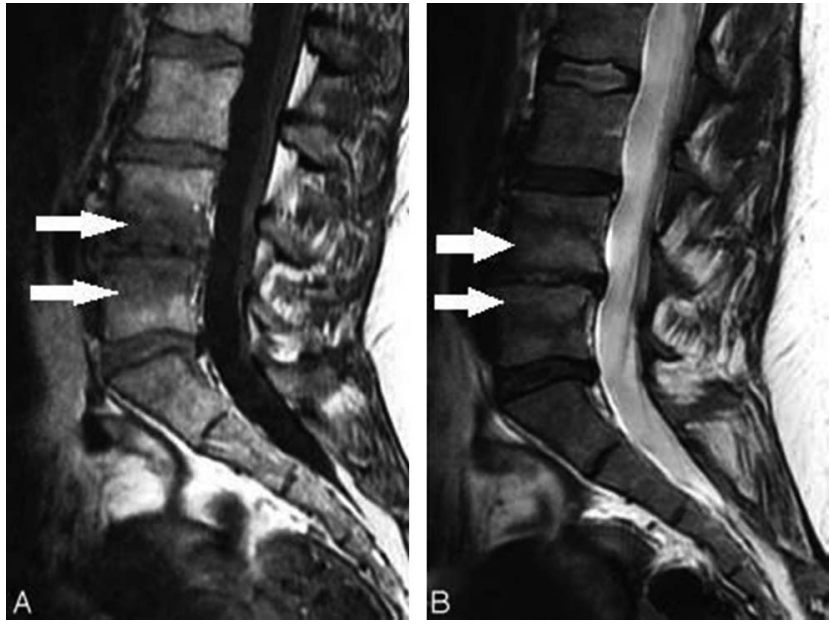

Figure 1. Modic changes type 1 (arrows): (A) Hypointense on T1WI. (B) Hyperintense on T2WI.

showed an increase in MC type 1 in follow-up of patients with LBP. Kjaer et $\mathrm{al}^{8,9}$ also showed strong association between MC and LBP and also showed that MC type 1 and $\mathrm{MC}$ at the L5-S1 level are more related to LBP than are $\mathrm{MC}$ at other levels. Carragee et $\mathrm{al}^{10}$ and Toyone et $\mathrm{al}^{11}$ also found association between MC and LBP. Ohtori et $\mathrm{al}^{12}$ found that presence of immunoreactive nerve fibers in the end-plate cartilage and a high number of cytokines such as tumor necrosis factor is cause for LBP in MC. After establishing that MC are strongly associated with LBP, knowing their etiology will help to address the problem. Although the etiology of MC remains poorly understood, previously it was thought to be associated with the degenerative process only. However, $\mathrm{MC}$ are not specific to the

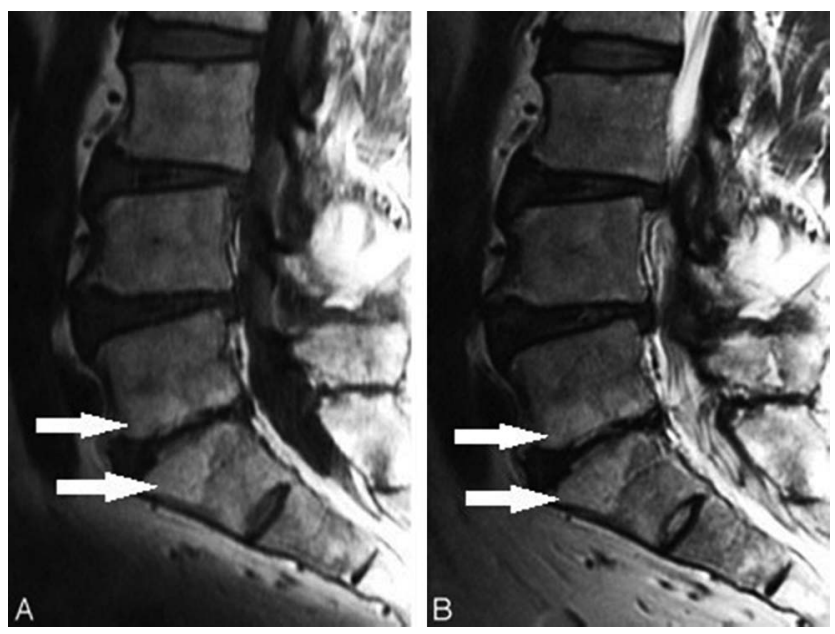

Figure 2. Modic changes type 2 (arrows): (A) Hyperintense on T1WI. (B) Isointense or hyperintense on T2WI.
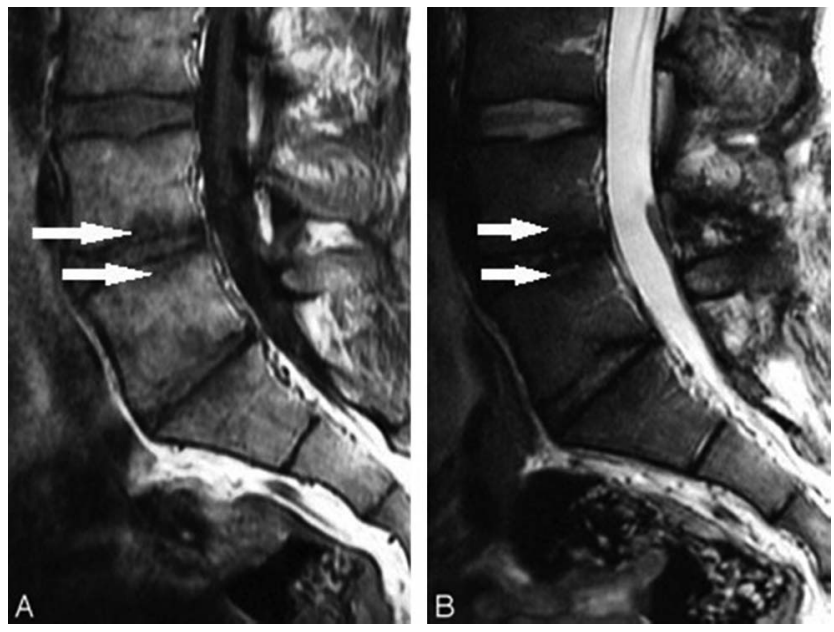

Figure 3. Modic changes type 3 (arrows): (A) Hypointense on T1WI. (B) Hypointense on T2WI.

degenerative process only ${ }^{13}$ and can be seen with different conditions such as infectious, degenerative, and immunological diseases. According to the current literature, there are two possible mechanisms: biomechanical and biochemical causes. ${ }^{14}$ The biomechanical mechanism relies mainly on vertebral end-plate changes due to a degenerative process. Disc degeneration leads to end-plate calcification and vertebral end plates exhibit altered structure and microfailure. ${ }^{15}$ Disc degeneration leads to uneven distribution of loads across the entire disc and thus may contribute to end-plate fissures. ${ }^{2}$ The biochemical mechanism is the one more studied and focuses on increases in inflammatory mediators. Crock et $\mathrm{al}^{16,17}$ showed an increase in the inflammatory mediator in the nucleus pulposus, leading to LBP. Braithwaite et $\mathrm{al}^{18}$ showed in their study that MC possibly resulted from the inflammatory reaction to the toxic substances from a degenerative disc. Albert et $\mathrm{al}^{19}$ suggested bacteriological etiology for MC. The present study focuses on finding an etiological correlation of MC with bacterial infection. Although there are studies that show the relation of MC to infectious discitis, these studies were based on isolation of bacteria by the culture method or the detection of increase in various proinflammatory markers. As such, the culture isolation is considered to be very poor in sensitivity, and surrogate markers of inflammation are very much nonspecific. In the present study, bacterial infection was identified by polymerase chain reaction (PCR) and by finding 16s DNA, which is specific for bacteria. 


\section{MATERIALS AND METHOD}

This was a prospective nonrandomized study that involved 20 patients of either sex with ages ranging from 20 to 65 years. The study was conducted at the Department of Orthopaedics, Institute of Medical Sciences, Banaras Hindu University, Varanasi, India.

The inclusion criteria were

- back pain for at least 6 months;

- patients with MC at lumbar spine level on MRI.

The exclusion criteria were

- history of recent viral or bacterial infections (within 6 months);

- past or present history of tumor, trauma, or any surgical intervention in the spine;

- having received epidural steroid injection;

- having undergone previous discectomy at the index level.

From each patient, $5 \mathrm{~mL}$ of venous blood were collected under aseptic conditions and sent for complete blood count, erythrocyte sedimentation rate, and quantitative $\mathrm{C}$-reactive protein in their respective vials.

At least $1 \mathrm{~mL}$ of intervertebral disc was collected from each patient under aseptic conditions in the operating theater during discectomy and stored in a sterile container containing sterile normal saline. This sample was sent to the Department of Microbiology for PCR study. In the present study we have targeted the conserved gene of the bacteria (ie, 16s ribosomal DNA). We have used a universal eubacteria nested-amplification protocol that may detect quantities as small as picograms of bacterial DNA. For the qualitative variables, Pearson $\chi^{2}$ test and Fisher exact test were applied to test for significance. Informed consent was taken from all the patients.

\section{RESULTS}

Among the 20 cases of patients who had LBP and MC in MRI, $13.5 \%$ showed raised leucocytosis, $28.6 \%$ showed raised ESR, and $72.7 \%$ showed raised quantitative C-reactive protein. Moreover, $90 \%$ of the cases showed presence of bacteria in PCR study. In this study we have found the amplification of the $16 \mathrm{~s}$ DNA sequence in $90 \%$ of the patients having MC along with LBP. When the amplicons (amplified products) from 18 different specimens were subjected to restriction enzyme analysis, EcoR1 yielded 2 bands of equal size in 17 of the samples, whereas 1 had a different banding pattern. This observation suggests that the bacteria amplified might be the same in most cases (Figures 4 and 5).

\section{DISCUSSION}

The basic objective of this study was to know whether bacterial infection is associated with MC. There are few studies that support our findings. In a 2008 study, Albert et al ${ }^{19,20}$ claimed that a disc herniation was the entry point of the bacteria and that MC likely were the result of the entry of bacteria, resulting in edema and inflammation surrounding the extruded nuclear material. However, this hypothesis has not been supported up to now. In the Albert et al ${ }^{19,20}$ study, $46 \%$ of the 61 patients with a lumbar disc herniation were found to have microorganisms present in extruded nuclear tissue. The microorganism most frequently cultured was the anaerobic bacterium Propionibacterium acnes. The discs from which the anaerobic bacteria were isolated were statistically significantly more likely to develop $\mathrm{MC}$ than those in which no bacteria or aerobic bacteria were detected $(P<$ .0038). The findings of this study could be interpreted as support for the theory that the occurrence of MC type 1 in the vertebrae adjacent to the previously herniated disc might be the edema surrounding an infected disc. Ohtori et $\mathrm{al}^{21}$ in their 2-year follow-up study reported that $4.2 \%$ of 71 patients with $\mathrm{MC}$ were diagnosed as having pyogenic spondylitis. They too used the culture method to isolate the bacteria. As expected, these 2 culture-based studies detected the presence of bacteria in small proportions. Because our study was based on molecular detection, our bacterial detection rate was quite high. Few other studies also showed that following a breach of the outer annulus fibrous after herniation of the nucleus pulposus, new capillarization occurred around the extruded nucleus pulposus during a short period of time, ${ }^{22-25}$ which leads to inflammation and macrophage aggregation. ${ }^{23-26}$ Anaerobic bacteria may enter the disc through the breach, causing a lowvirulent and slowly developing infection in the disc. Due to the fact that a disc is an avascular structure, it is an ideal environment for the growth of anaerobic bacteria. Albert et $\mathrm{al}^{27}$ and Modic et 


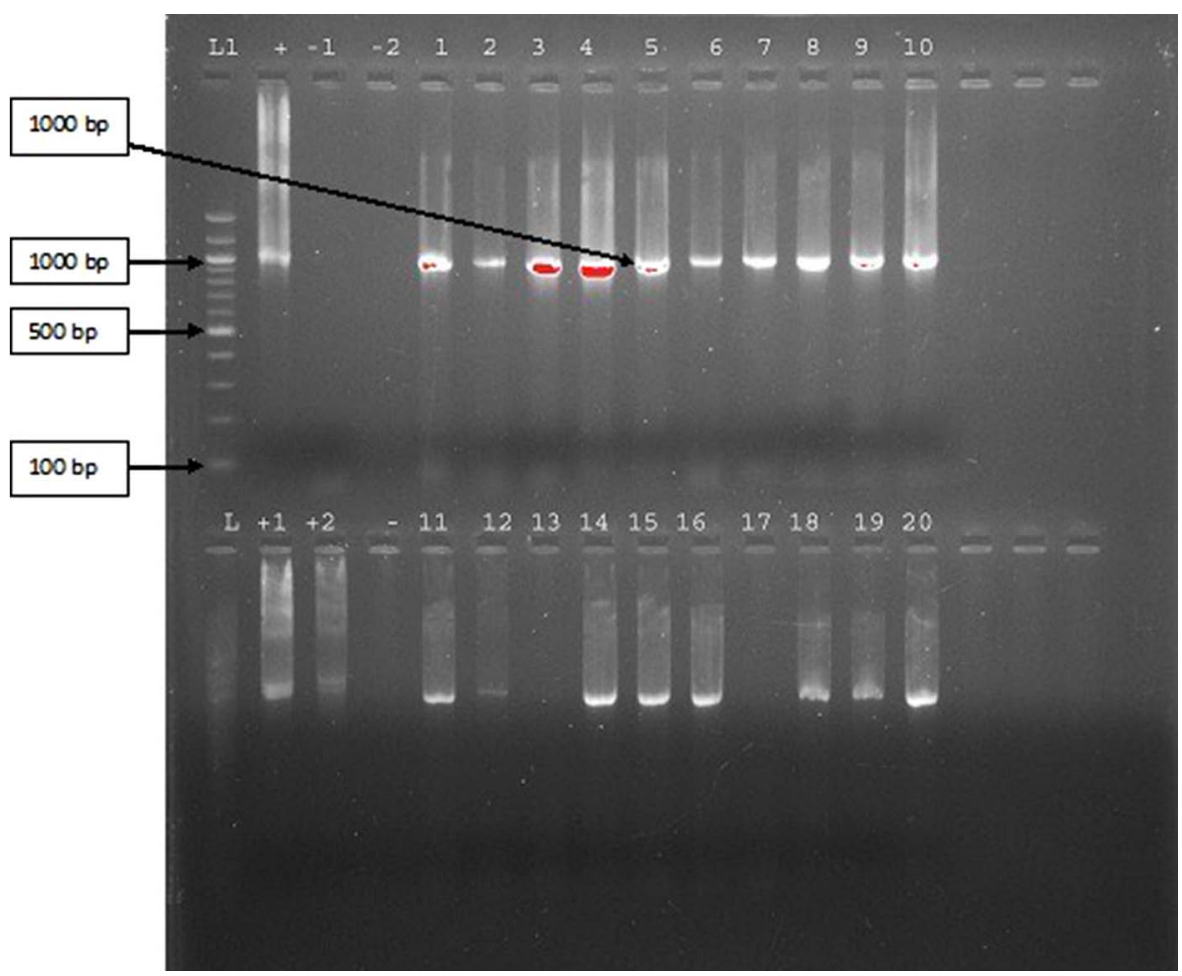

Figure 4. Depicting the $16 \mathrm{~s}$ amplified DNA products of the 20 samples of intervertebral discs. (Among the 20 samples, sample no. 13 and sample no. 17 did not show the presence of bacterial DNA.)

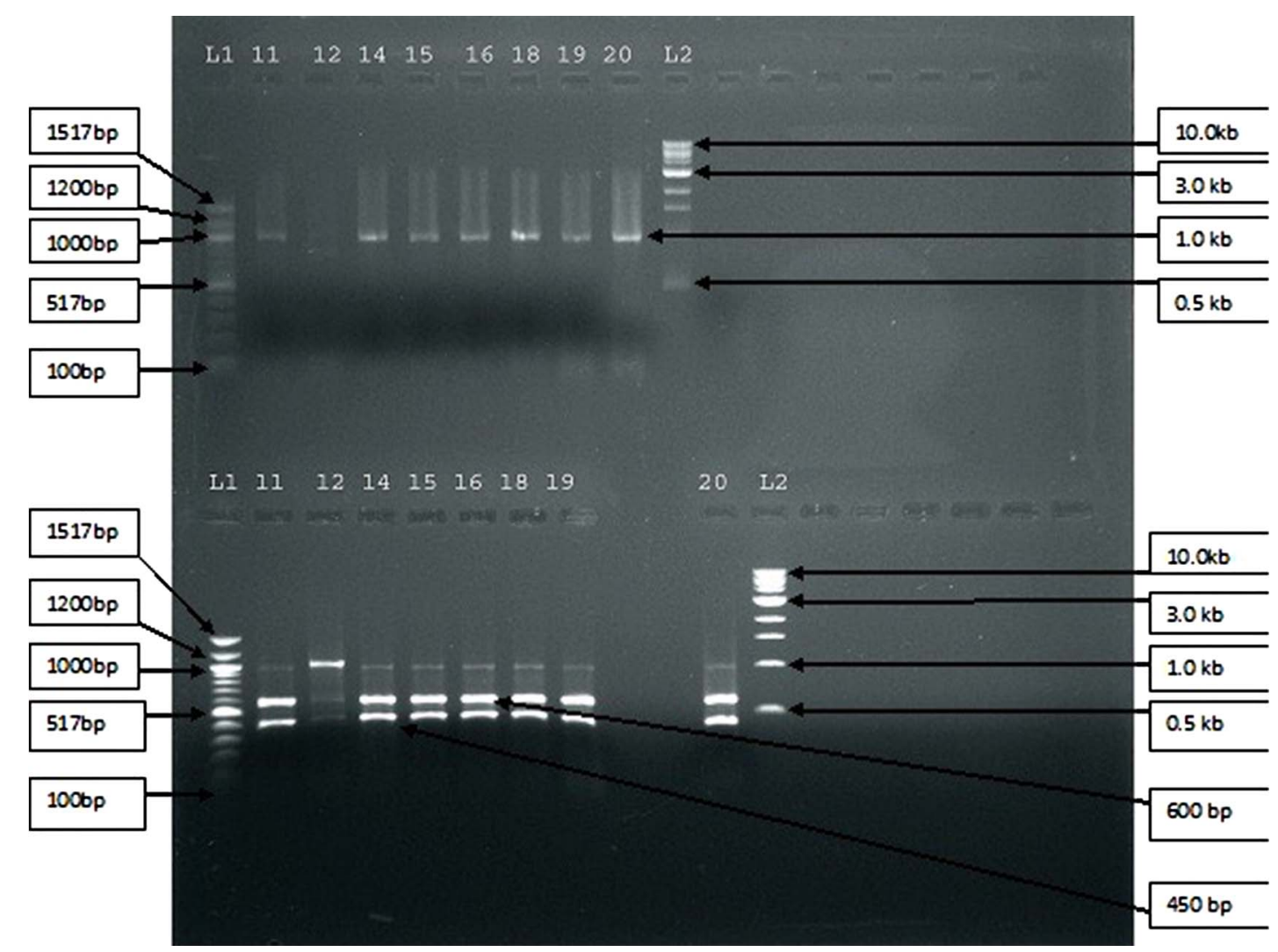

Figure 5. Depicting the restriction analysis of 18 amplicons from $16 \mathrm{~s}$ amplification. Upper half of the figure represents BamH1 enzyme-digested products and the lower half of the figure represents EcoR1 enzyme-digested products. 
$\mathrm{al}^{28}$ showed a positive result of antibiotic treatment on MC in 2 small and uncontrolled studies. Aghazadeh et $\mathrm{al}^{29}$ found in their study of 120 patients that the 16s DNA gene was identified in $38.3 \%$ of the disc sample.

\section{CONCLUSIONS}

Diagnosing patients with LBP with specific anatomical pathological etiology is challenging, ${ }^{30}$ and because MC are strongly associated with LBP, this study focused on finding an etiological correlation between MC and bacterial infection. After the study, we can conclude that vertebral end plate changes (Modic changes) may have an infective etiology such as bacteria that may have led to a local inflammatory process and raised levels of acutephase reactants. This local inflammation might have led to vertebral end plate changes that appear in the MRI as MC. Because this is a very small study, a study involving large numbers might be able to resolve the issue more clearly. In our study, the focus was on finding a correlation between MC and bacterial infection by PCR and 16s DNA but not on finding any specific bacteria. If the DNA sequencing data become available and some specific bacteria are found to be associated, that would be more helpful. Amplification of 2 or 3 genes of that particular bacteria in the intervertebral disc from a patient can resolve the issue further. However, it needs further extensive study involving a large number of cases, which might modify the current concepts in the treatment of back pain associated with MC.

\section{REFERENCES}

1. de Roos A, Kressel H, Spritzer C, Dalinka M. MR imaging of marrow changes adjacent to end plates in degenerative lumbar disk disease. AJR Am J Roentgenol. 1987;149(3):531-534.

2. Modic MT, Steinberg PM, Ross JS, Masaryk TJ, Carter JR. Degenerative disk disease: assessment of changes in vertebral body marrow with MR imaging. Radiology. 1988;166(1 Pt 1):193-199.

3. Modic MT, Masaryk TJ, Ross JS, Carter JR. Imaging of degenerative disk disease. Radiology. 1988;168(1):177-186.

4. Miller G. The spine. In: Berquist T, ed. MRI of the Musculoskeletal System. 2nd ed. New York: Raven; 1990.

5. Weishaupt D, Zanetti M, Hodler J, et al. Painful lumbar disk derangement: relevance of endplate abnormalities at MR imaging. Radiology. 2001;218(2):420-427.

6. Bendix T, Sorensen JS, Henriksson GAC, Bolstad JE, Narvestad EK, Jensen TS. Lumbar Modic changes-a comparison between findings at low- and high-field magnetic resonance imaging. Spine. 2012;37(20):1756-1762.
7. Albert HB, Manniche C. Modic changes following lumbar disc herniation. Eur Spine J. 2007;16(7):977-982. doi:10.1007/ s00586-007-0336-8

8. Kjaer P, Korsholm L, Bendix T, Sorensen JS, LeboeufYde C. Modic changes and their associations with clinical findings. Eur Spine J. 2006;15(9):1312-1319. doi:10.1007/ s00586-006-0185-X

9. Kjaer P, Leboeuf-Yde C, Korsholm L, Sorensen JS, Bendix T. Magnetic resonance imaging and low back pain in adults: a diagnostic imaging study of 40-year-old men and women. Spine. 2005;30(10):1173-1180. doi:10.1097/01.brs. 0000162396.97739 .76

10. Carragee EJ, Alamin TF, Miller JL, Carragee JM. Discographic, MRI, and psychosocial determinants of low back pain disability and remission: a prospective study in subjects with benign persistent back pain. Spine J. 2005;5(1):24-35. doi: $10.1016 /$ j.spinee.2004.05.250

11. Toyone T, Takahashi K, Kitahara H, Yamagata M, Murakami M, Moriya H. Vertebral bone-marrow changes in degenerative lumbar disc disease: an MRI study of 74 patients with low back pain. J Bone Joint Surg Br. 1994;76(5):757-764.

12. Ohtori $S$, Inoue $G$, Ito $T$, et al. Tumor necrosis factorimmunoreactive cells and PGP 9.5-immunoreactive nerve fibers in vertebral endplates of patients with discogenic low back pain and Modic type 1 or 2 changes on MRI. Spine. 2006;31:10261031.

13. Vital JM, Gille O, Pointillart V, et al. Course of Modic 1 six months after lumbar posterior osteosynthesis. Spine. 2003;28(7):715-721. doi:10.1097/00007632-200304010-00017

14. Zhang Y-H, Zhao C-Q, Jiang L-S, Chen X-D, Dai L-Y. Modic changes: a systematic review of the literature. Eur Spine J. 2008;17(10):1289-1299. doi:10.1007/s00586-008-0758-y

15. Gruber HE, Hanley EN Jr. Recent advances in disc cell biology. Spine. 2003;28:186-193. doi:10.1097/00007632200301150-00017

16. Crock HV. A reappraisal of intervertebral disc lesions. Med J Aust. 1970;1:983-989.

17. Crock HV. Internal disc disruption: a challenge to disc prolapse fifty years on. Spine. 1986;11:650-653. doi:10.1097/ 00007632-198607000-00028

18. Braithwaite I, White J, Saifuddin A, Renton P, Taylor BA. Vertebral end-plate (Modic) changes on lumbar spine MRI: correlation with pain reproduction at lumbar discography. Eur Spine J. 1998;7:363-368. doi:10.1007/s005860050091.

19. Albert HB, Kjaer P, Jensen TS, Sorensen JS, Bendix T, Manniche C. Modic changes: possible causes and relation to low back pain. Med Hypotheses. 2008;70:361-368. doi:10.1016/ j.mehy.2007.05.014

20. Albert HB, Lambert P, Rollason J, et al. Does nuclear tissue infected with bacteria following disc herniations lead to Modic changes in the adjacent vertebra? Eur Spine J. 2013;22(4):690-696.

21. Ohtori S, Koshi T, Yamashita M, Yamauchi K, Inoue G, Takahashi K. Existence of pyogenic spondylitis in Modic type 1 change without other signs of infection: 2-year follow-up. Eur Spine J. 2010;19(7):1200-1205.

22. Doita M, Kanatani T, Harada T, Mizuno K. Immunohistologic study of the ruptured intervertebral disc of the lumbar spine. Spine. 1996;21(2):235-241.

23. Ito T, Yamada M, Ikuta F, et al. Histologic evidence of 
absorption of sequestration type herniated disc. Spine. 1996;21(2):230-234.

24. Hirabayashi S, Kumano K, Tsuiki T, Eguchi M, Ikeda S. A dorsally displaced free fragment of lumbar disc herniation and its interesting histologic findings. A case report. Spine. 1990;15:1231-1233.

25. Lindblom K, Hultquist G. Absorption of protruded disc tissue. J Bone Joint Surg. 1950;32A:557-560.

26. Gronblad M, Virri J, Tolonen J, et al. A controlled immunohistochemical study of inflammatory cells in disc herniation tissue. Spine. 1994;19:2744-2751.

27. Albert HB, Manniche C, Sorensen JS, Deleuran BW. Antibiotic treatment in patients with low back pain associated with Modic type 1 changes: a pilot study. $\mathrm{Br}$ J Sports Med. 2008;42(12):969-973. doi:10.1136/bjsm.2008.050369

28. Modic MT, Pavlicek W, Weinstein MA, et al. Magnetic resonance imaging of intervertebral disk disease. Clinical and pulse sequence considerations. Radiology. 1984;152:103-111.

29. Aghazadeh J, Salehpour F, Ziaeii E, et al. Modic changes in the adjacent vertebra due to disc material infection with Propionibacterium acnes in patient with limber disc herniation. Eur Spine J. 2017;26(12):3129-3134. doi:10.1007/s00586-0164887-4

30. Waddell G. Volvo award in clinical sciences. A new clinical model for the treatment of low-back pain. Spine. 1987;12:632-644.

Disclosures and COI: The authors received no funding for this study and report no conflicts of interest.

Corresponding Author: Alok Rai, Senior Resident, Department of Orthopaedics, Institute of Medical Sciences, Banaras Hindu University, Room No. 36 Shushruta Hostel Trauma Centre, BHU Varanasi, Uttar Pradesh, India 221005. Phone: +917860801903; Email: alokrairaman@ gmail.com.

Published 11 November 2020

This manuscript is generously published free of charge by ISASS, the International Society for the Advancement of Spine Surgery. Copyright (C) 2020 ISASS. To see more or order reprints or permissions, see http://ijssurgery.com. 